\title{
A Computational Study on Some Pyridine-Substituted-Bis-1,2,4-Triazole Derivatives and Investigation of Their Catalytic Activities
}

\author{
Ragip Adiguzel ${ }^{1 *}$, Ebru Aktan ${ }^{2}$, Enes Evren ${ }^{3}$, Ahmet Çetin ${ }^{4}$ \\ ${ }^{1}$ Munzur University, Vocational School of Tunceli, Department of Chemistry and Chemical Process \\ Technologies/Laboratory Technology Program, 62000 Tunceli, Turkey \\ ${ }^{2}$ Gazi University, Faculty of Sciences, Department of Chemistry, 06500 Teknikokullar Ankara, Turkey \\ ${ }^{3}$ Inonu University, Catalysis Research and Application Center, 44280 Malatya, Turkey \\ ${ }^{4}$ Bingol University, Faculty of Arts and Sciences, Department of Chemistry, 12000 Bingol, Turkey \\ *radiguzel@munzur.edu.tr ${ }^{\mathrm{D}}$,ebruaktan@gazi.edu.tr ${ }^{\mathrm{D}}$,enesevren20@gmail.com ${ }^{\mathrm{D}}$, acetin@bingol.edu.tr $\mathrm{D}$ \\ Received date: 04.09.2020, Accepted date: 24.12.2020
}

\begin{abstract}
In this work were specified catalytic activity of pyridine-substituted-bis-1,2,4-triazole (PBTT) derivative ligands 5,5'(pyridine-2,5-diyl)bis(4-ethyl-4H-1,2,4-triazole-3-thiol) $\left(\mathrm{L}_{1}\right)$ and 5,5'-(pyridine-2,5-diyl)bis(4-phenyl-4H-1,2,4-triazole-3thiol) $\left(\mathrm{L}_{2}\right)$ in biaryl synthesis in situ-reaction condition. Catalytic activities are determined in terms of conversion percentages to derivatives of biaryl of aryl bromides by GC-MS. The highest catalytic effect for $\mathrm{L}_{1}$ ligand was measured as $61 \%$ with $4-$ bromobenzaldehyde. Apart from catalytic activity studies, some structural properties of related ligands were discussed by computational methods. As a result, the ground state geometries, frontier molecular orbitals (FMOs) and also the maps of molecular electrostatic potential (MEP) of $\mathrm{L}_{1}$ and $\mathrm{L}_{2}$ ligands were obtained using DFT/B3LYP/6-31+G(d) calculations. Additionally, the global reactivity descriptors were reached using the FMOs calculations.
\end{abstract}

Keywords: Catalytic activity, density-functional theory, in situ-reaction condition, pyridine-substituted-bis-1,2,4-triazole derivatives

\section{Bazı Piridin-Sübstitüe-Bis-1,2,4-Triazol Türevleri Üzerine Hesaplamalı Bir Çalışma ve Katalitik Aktivitelerinin İncelenmesi}

Öz

Bu çalışmada piridin-sübstitüe-bis-1,2,4-triazol türevi (PBTT) ligandlarının ( $\mathrm{L}_{1}$ : 5,5'-(piridin-2,5-diil)bis(4-etil-4H1,2,4-triazol-3-tiyol) ve $\mathrm{L}_{2}$ : 5,5'-(piridin-2,5-diil)bis(4-fenil-4H-1,2,4-triazol-3-tiyol)) biaril sentezinde in situ-reaksiyon koşullarında katalitik aktiviteleri belirlendi. Katalitik aktiviteler, GC-MS ile aril bromürlerin biaril türevlerine dönüşüm yüzdeleri cinsinden belirlendi. $\mathrm{L}_{1}$ ligandı için en yüksek katalitik etki 4-bromobenzaldehit ile \%61 olarak ölçüldü. Katalitik aktivite çalışmalarının yanı sıra, ilgili ligandların bazı yapısal özellikleri hesaplama yöntemleriyle tartışıldı. Sonuç olarak, DFT/B3LYP/6-31+G(d) hesaplamaları kullanılarak $\mathrm{L}_{1}$ ve $\mathrm{L}_{2}$ ligandlarının temel durum geometrileri, sınır moleküler orbitalleri (FMOs) ve ayrıca moleküler elektrostatik potansiyel (MEP) haritaları elde edildi. Ek olarak, global reaktivite tanımlayıcıları FMOs hesaplamaları kullanılarak elde edildi.

Anahtar kelimeler: Katalitik aktivite, yoğunluk fonksiyonel teorisi, in-situ reaksiyon koşulları, piridin-sübstitüe-bis-1,2,4-triazol türevleri

\section{INTRODUCTION}

(PBTT) derivatives that contain triazole and pyridine ring have a significant place medically and pharmacologically (Ahirwar et al., 2017). Numerous studies have been reported about medical and pharmacological applications of these compounds include significant biological activities in the literature (Bulut et al., 2018). Besides the biological applications mentioned, mercapto-1,2,4-triazoles antibacterial and antioxidant activities, the using of 1,2,4-triazole derivatives in different therapeutical drug candidates as antimicrobial, anti-inflammatory and sedative agents can be exemplified to these application fields. Compounds in this class can give different heterocyclic compounds such as thiazolotriazoles, triazolothiadizoles, triazolothiazepines, and triazolothiadiazines via various reactions with numerous reagents in terms of synthetic organic chemistry. These compounds are preferred as easily accessible nucleophilic centers for 
the preparation of $\mathrm{N}$-bridged heterocyclic compounds due to their amino and mercapto groups (Muthal et al., 2010; Muneer et al., 2014; Bulut et al., 2018). Moreover, catalytic activities of (PBTT) derivatives besides pyridine-substituted-1,2,4-triazole derivatives weren't investigated in detail (Turek et al., 2014).

In addition, some studies reported on the electronic structures of heterocyclic thione derivatives and the thiol-thione tautomeric equilibrium (Coyanis et al., 2002; Cansiz et al., 2009). In the X-ray single crystallographic analysis of 1,2,4-triazole compounds, $\mathrm{N}-\mathrm{H}$...S hydrogen bonds forming dimers which are linked into a chain by N-H...N hydrogen bonds (Dege et al., 2004; Dege et al., 2005).

Actually, we aimed to investigate the catalytic activities of palladium complexes that include (PBTT) derivatives. By reason of solubility and purification problems during the synthesis of the complexes of related ligands came to light, for this reason, we decided to investigate the catalytic activities of these ligands in situ-reaction conditions. Information about the molecular geometry and electronic properties were obtained by DFT calculations.

\section{MATERIAL AND METHOD}

(PBTT) derivatives $\left(\mathrm{L}_{1}:\right.$ 5,5'-(pyridine-2,5diyl)bis(4-phenyl-4H-1,2,4-triazole-3-thiol) and $\mathrm{L}_{2}$ : 5,5'-(pyridine-2,5-diyl)bis(4-ethyl-4H-1,2,4-triazole-3thiol) were synthesized according to the given procedure in the literature (Çetin and Dayan, 2009). The B3LYP/6-31+G(d) optimized structures of the $\mathrm{L}_{1}$ and $\mathrm{L}_{2}$ ligands are given in Figure 1.

According to Suzuki coupling reaction, the synthesis of biaryl between aryl bromide and phenylboronic acid was performed in situ-reaction conditions.

\section{General Procedure for the Suzuki Coupling Reaction in situ-Reaction Conditions}

(PBTT) derivatives $\mathrm{L}_{1}$ and $\mathrm{L}_{2}(2.0 \mathrm{mmol} \%), \mathrm{PdCl}_{2}$ (1.0 mmol \%), aryl bromide (1.0 mmol \%), phenylboronic acid (1.0 mmol \%), $\mathrm{K}_{2} \mathrm{CO}_{3}(2 \mathrm{mmol} \%)$, and $2 \mathrm{~mL} i-\mathrm{PrOH} / \mathrm{H}_{2} \mathrm{O}(1: 3)$, were taken up to a small Schlenk tube and the temperature of the reaction mixture was raised to $80{ }^{\circ} \mathrm{C}$ for $15 \mathrm{~h}$. The purification was completed via GC and the yield of the reaction was based on aryl bromide.

\section{Computational Details}

The ground-state geometries of the $\mathrm{L}_{1}$ and $\mathrm{L}_{2}$ ligands are obtained using the B3LYP method at a 6-
$31+\mathrm{G}(\mathrm{d})$ basis set. The geometric parameters with atom numbering of the $\mathrm{L}_{1}$ and $\mathrm{L}_{2}$ ligands are given in Appendix 1. The vibrational frequencies are calculated to show that these structures did not have an imaginary frequency. Gaussian 09 program package is used for all calculations (Frisch et al., 2010).

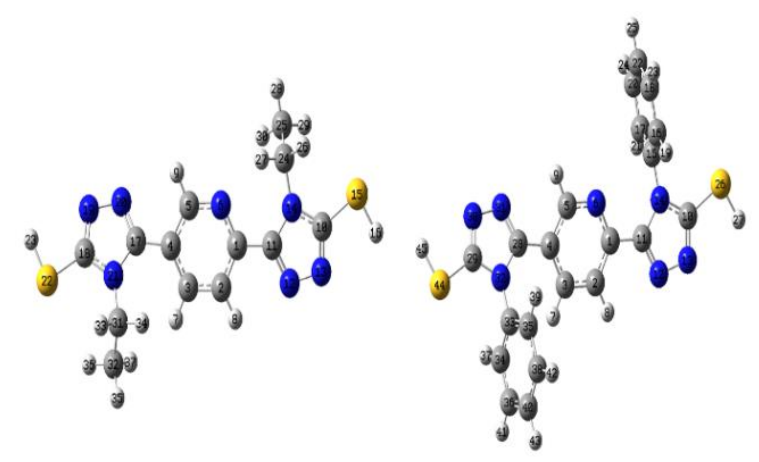

Figure 1. The optimized structures of the $\mathrm{L}_{1}(\mathrm{left})$ and $\mathrm{L}_{2}$ (right) ligands with atom numbering scheme

(B3LYP/6-31+G(d))

\section{RESULTS AND DISCUSSION}

Catalytic Activity Results of the $L_{1}$ and $L_{2}$ Ligands

In the Suzuki coupling reaction known as the C-C coupling reaction in the biaryl synthesis, the bound groups in the selected substrates $\left(-\mathrm{CH}=\mathrm{O},-\mathrm{CH}_{3} \mathrm{C}=\mathrm{O}\right.$ and $\left.-\mathrm{OCH}_{3}\right)$ are in the para-position and therefore, have no steric effect. However, if an electron-withdrawing group is bound to the aromatic ring in the substrate, the $\mathrm{Ar}-\mathrm{Br}$ bond is weakened, whereas the electron donor group is bound, the electron density of the Ar-Br bond is increased and the $\mathrm{C}-\mathrm{Br}$ bond becomes difficult to break (İnce, 2016).

The catalytic activity of the $\mathrm{L}_{1}$ ligand in the Suzuki coupling reaction that is performed in situ reaction conditions was determined $32 \%, 52 \%$, and $61 \%$, respectively, when used 4-bromo anisole, 4-bromo acetophenone, and 4-bromo benzaldehyde.

The bonded groups on aromatic ring of substrate lead to the increase in catalytic activity. This increase is compatible with electron-withdrawing group or electron donor group at the aromatic ring of a substrate (Ince, 2016). However, the obtained catalytic activity results are lower when compared to the catalytic activity of the benzimidazole derivatives (Özdemir et al., 2007; Yiğit et al., 2010).

When using the ligand of $\mathrm{L}_{1}$ in the synthesis of biaryl, $52 \%$, and $61 \%$ yield were achieved with 4 bromoacetophenone and 4-bromobenzaldehyde. The 
$\mathrm{L}_{1}$ ligand includes bound ethyl group to either triazole nitrogen atom, otherwise, the ligand of $\mathrm{L}_{2}$ has bound phenyl group to either nitrogen atom of triazole ring. The same experiments for either substrate were repeated by using $\mathrm{L}_{2}$ ligand and was obtained $48 \%$ and 50\% yield respectively with 4bromobenzaldehyde and 4-bromoacetophenone. A control experiment with $\mathrm{PbCl}_{2}$ indicated that the Suzuki coupling reaction resulted in lower yield in the absence of $\mathrm{L}_{1}$ ligand (See experiment number 6 Table 1).

\section{Computational Study Results}

Potential energy surface (PES) scans are done around the six single bonds to find the most stable conformers of $\mathrm{L}_{1}$ and $\mathrm{L}_{2}$ at $\mathrm{HF} / 6-31 \mathrm{G}(\mathrm{d})$ level of theory. The mentioned dihedral angles are $\tau_{1}=\mathrm{N} 6-\mathrm{C} 1-$ C11-N12, $\tau_{2}=\mathrm{C} 5-\mathrm{C} 4-\mathrm{C} 17-\mathrm{N} 21, \quad \tau_{3}=\mathrm{N} 21-\mathrm{C} 18-\mathrm{S} 22-$ $\mathrm{H} 23, \tau_{4}=\mathrm{C} 17-\mathrm{N} 21-\mathrm{C} 31-\mathrm{C} 32, \tau_{5}=\mathrm{C} 11-\mathrm{N} 14-\mathrm{C} 24-\mathrm{C} 25$ and $\tau_{6}=\mathrm{N} 6-\mathrm{C} 1-\mathrm{C} 11-\mathrm{N} 12$ for $\mathrm{L}_{1}$. The scan runs are performed by varying the dihedral angles at a step of $10^{\circ}$ in the range $0-360^{\circ}$. Then the most stable conformers of $\mathrm{L}_{1}$ and $\mathrm{L}_{2}$ are optimized on the B3LYP method at $6-31+\mathrm{G}(\mathrm{d})$ basis set to give the groundstate geometries of $\mathrm{L}_{1}$ and $\mathrm{L}_{2}$ as seen in Figure 1 . Comparison of the Hartree-Fock (HF) and DFT methods, the DFT calculations based on the B3LYP level give much more sensitive results in predicting structural and electronic properties than HF methods. Therefore, we used DFT/ B3LYP method in our all other calculations. C3-C4-C28-N31 and N6-C1-C11N14 dihedral angles of $\mathrm{L}_{2}$ are calculated as $-149.13^{\circ}$ and $-6.98^{\circ}$, respectively. Phenyl rings twisted triazole rings with angels of $86.04^{\circ}(\mathrm{C} 11-\mathrm{N} 14-\mathrm{C} 15-\mathrm{C} 17)$ and $69.46^{\circ}$ (C28-N32-C33-C35). The bond lengths C10$\mathrm{S} 26$ and $\mathrm{C} 29-\mathrm{S} 44$ are found as $1.764^{\circ}$. The dihedral angles of N32-C29-S44-H45 and N14-C10-S26-H27 are calculated as $177.81^{\circ}$ and $-179.65^{\circ}$, respectively. The corresponding dihedral angles of $\mathrm{L}_{1}$ are found as $171.07^{\circ}$ and $176.07^{\circ}$. As seen in Figure 1, the molecular shape of $\mathrm{L}_{2}$ is almost similar to $\mathrm{L}_{1}$.

\section{HOMO-LUMO Gaps and Reactivity Descriptors}

Molecular orbital theory is widely used to understand important properties of organic molecules such as their electronic, biological, optical and chemical reactivity. According to frontier molecular orbital theory, the highest occupied molecular orbitals (HOMO) and lowest unoccupied molecular orbitals (LUMO) provide information about the chemical reactivity of the species (Özdemir Özmen et al., 2014; Gündüzalp et al., 2016; Özdemir Özmen et al., 2017). Furthermore, the difference between the HOMO and LUMO energy, so HOMO-LUMO energy gap, will helpful in measuring the optical polarizability, chemical softness-hardness, biological activity and kinetic stability of the molecules. The shapes of HOMO and LUMO of $\mathrm{L}_{1}$ and $\mathrm{L}_{2}$ are determined using the DFT/B3LYP method with 6-31G+(d) (Figure 2).

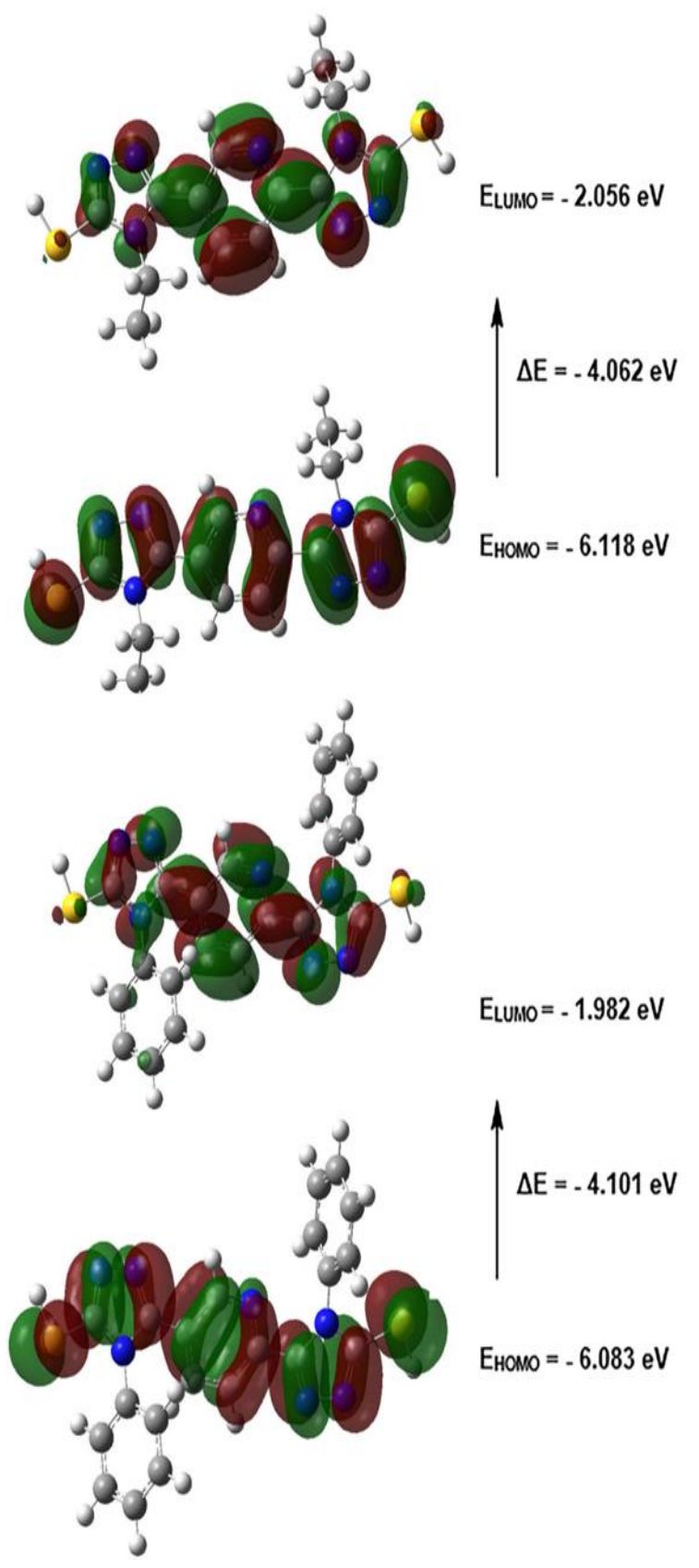

Figure 2. FMOs of the $\mathrm{L}_{1}$ (top) and $\mathrm{L}_{2}$ (bottom) ligands 
Table 1. The Suzuki coupling reaction of aryl bromides with phenylboronic acid in situ-reaction conditions $\left(\mathrm{PdCl}_{2} / \mathrm{L}_{1}\right)^{\mathrm{a}}$

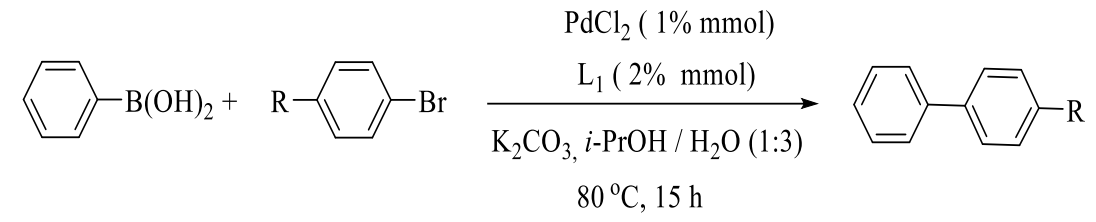

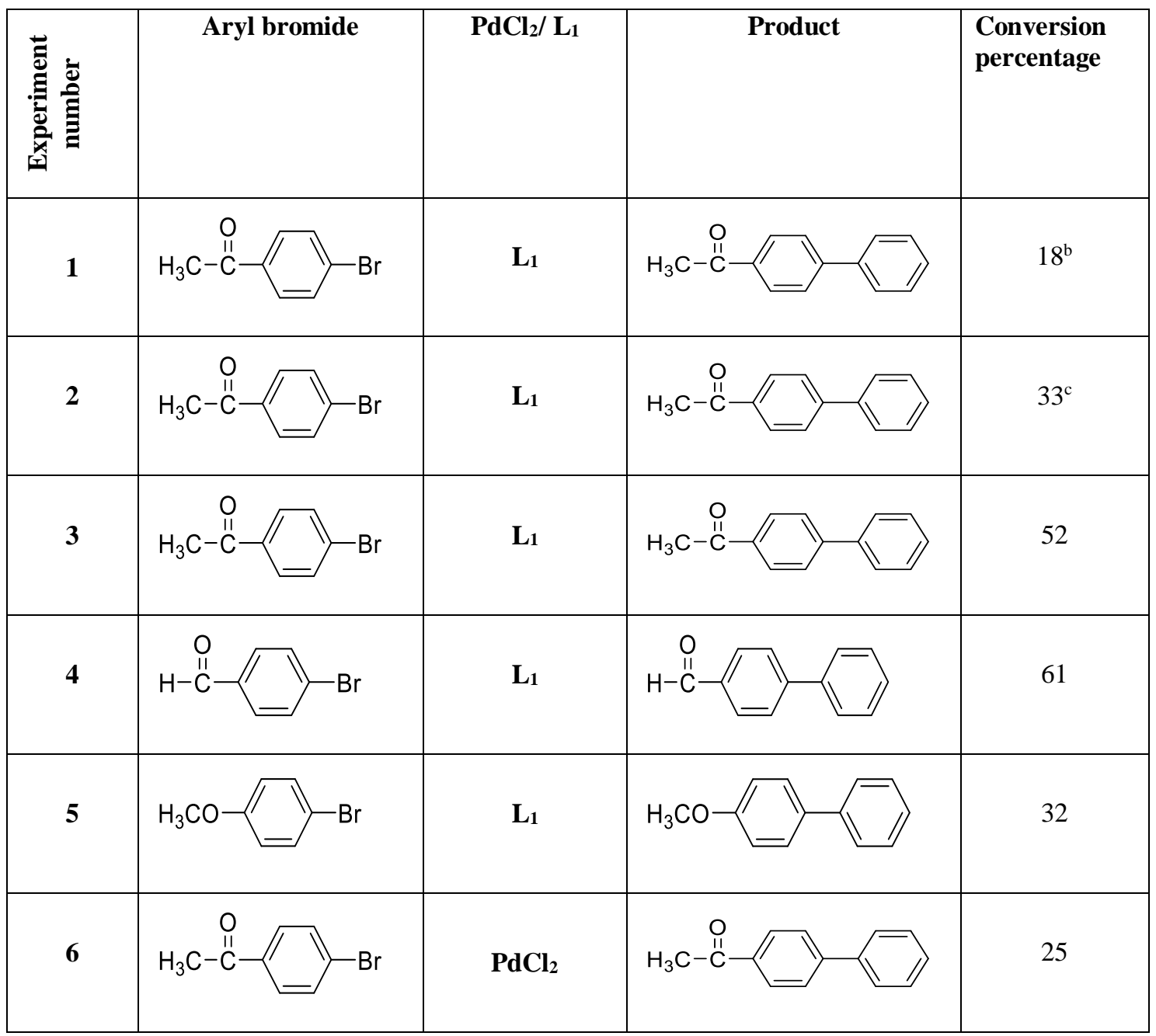

${ }^{a}$ Reaction conditions: $1 \mathrm{mmol}$ phenylboronic acid, $1 \mathrm{mmol}$ aryl bromide, $2 \mathrm{mmol} \mathrm{K} 2 \mathrm{CO}_{3}, 2 \mathrm{mmol} \mathrm{L}$, $2 \mathrm{~mL} i$ - $\mathrm{PrOH} / \mathrm{H}_{2} \mathrm{O}(1: 3)$, temperature $80{ }^{\circ} \mathrm{C}, 15 \mathrm{~h}$. ${ }^{\mathrm{b}}$ Solvent: 1,4-dioxane, ${ }^{\mathrm{c}}$ Reaction time: $8 \mathrm{~h}$

Table 2. Calculated global reactivity descriptors for ligands in $\mathrm{eV}$

\begin{tabular}{ccccccccc}
\hline Compound & $\mathrm{I}$ & $\mathrm{A}$ & $\Delta \mathrm{E}$ & $\mathrm{X}$ & $\mu$ & $\eta$ & $\mathrm{S}$ & $\omega$ \\
\hline $\mathrm{L}_{1}$ & 6.118 & 2.056 & 4.062 & 4.087 & -4.087 & 2.031 & 0.246 & 4.112 \\
$\mathrm{~L}_{2}$ & 6.083 & 1.982 & 4.101 & 4.033 & -4.033 & 2.051 & 0.244 & 3.965 \\
\hline
\end{tabular}


Table 3. The Suzuki coupling reaction of aryl bromides with phenylboronic acid in situ-reaction conditions $\left(\mathrm{PdCl}_{2} / \mathrm{L}_{2}\right)^{\mathrm{a}}$

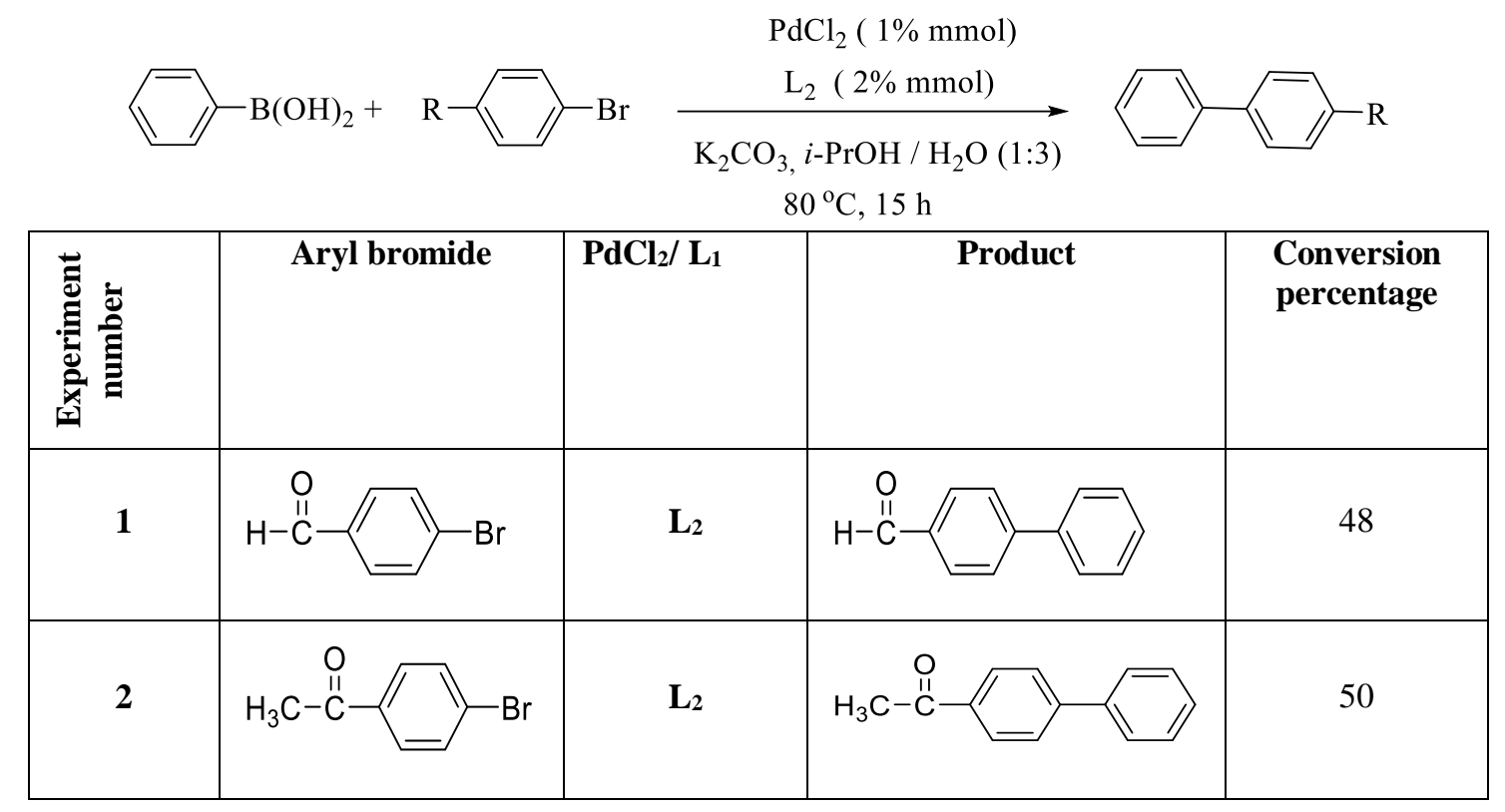

${ }^{a}$ Reaction conditions: 1 mmol phenylboronic acid, $1 \mathrm{mmol}$ aryl bromide, 2 mmol K $2 \mathrm{CO}_{3}, 2$ mmol L2, $2 \mathrm{~mL} i$-PrOH/ $\mathrm{H}_{2} \mathrm{O}$ (1:3), temperature $80^{\circ} \mathrm{C}, 15 \mathrm{~h}$

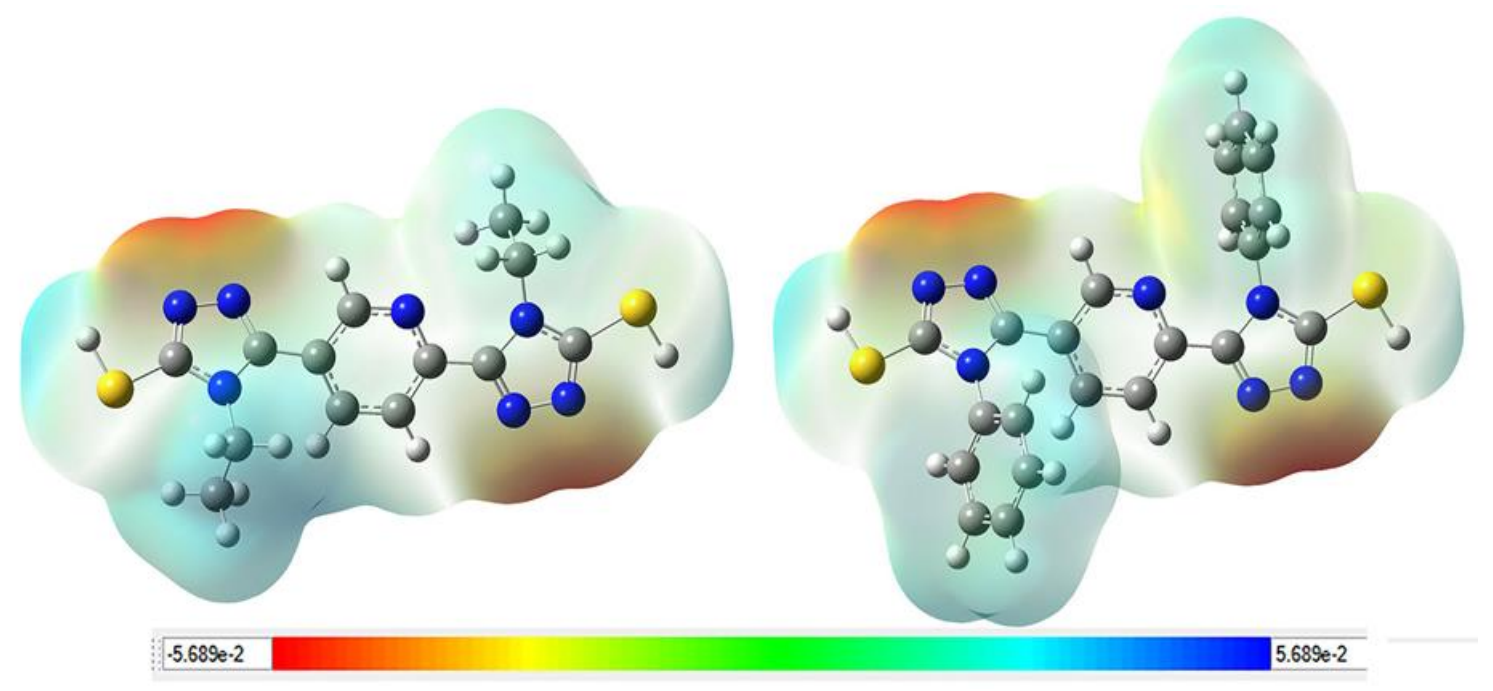

Figure 3. The molecular electrostatic potential (MEP) map of the $\mathrm{L}_{1}$ (left) and $\mathrm{L}_{2}$ (right) ligands

Global reactivity descriptors such as ionization potential $\left(\mathrm{I}=-\mathrm{E}_{\mathrm{HOMO}}\right)$, electron affinity $\left(\mathrm{A}=-\mathrm{E}_{\mathrm{LUMO}}\right)$, energy band gap $\left(\Delta \mathrm{E}=\mathrm{E}_{\mathrm{Lumo}}-\mathrm{E}_{\mathrm{HOMO}}\right)$, electronegativity $(\chi=\mathrm{I}+\mathrm{A} / 2)$, chemical potential $(\mu=$ - $\chi)$, global hardness $(\eta=\mathrm{I}-\mathrm{A} / 2)$, global softness $(\mathrm{S}=$ $1 / 2 \eta)$ and global electrophilicity index $\left(\omega=\mu^{2} / 2 \eta\right)$ were identified to predict global chemical reactivity trends of $\mathrm{L}_{1}$ and $\mathrm{L}_{2}$ ligands (Table 2). Global chemical reactivity trends can be predicted with global chemical reactivity descriptors.

The energies of HOMO and LUMO are calculated as $-6,118 \mathrm{eV}$ and $-2.056 \mathrm{eV}$ for $\mathrm{L}_{1}$, respectively. The electron densities of FMOs were located on the whole molecule except ethyl groups for 
$\mathrm{L}_{1}$. The energy of HOMO is calculated as $-6.083 \mathrm{eV}$ and the energy of LUMO is calculated $1.982 \mathrm{eV}$ for $\mathrm{L}_{2}$, respectively. Both of the FMOs consist of the whole molecular moiety except phenyl rings. The energy gap for ligands $\mathrm{L}_{1}$ and $\mathrm{L}_{2}$ are obtained as 4.062 $\mathrm{eV}$ and $4.101 \mathrm{eV}$, respectively. A soft molecule has a low energy gap. The energy band gap of $\mathrm{L}_{1}$ is lower than the energy band gap of $\mathrm{L}_{2}$, also $\mathrm{L}_{1}$ is a bit more polarizable than $\mathrm{L}_{2}$ and more reactive towards any chemical reactions than $\mathrm{L}_{2}$. The chemical hardness is expressed as the resistance of a molecule to changing its electron density with its environment. The less stable molecule is softer and hence more reactive. $\mathrm{L}_{1}$ also shows a bit lower chemical stability than $\mathrm{L}_{2}$ and the hardness of $\mathrm{L}_{1}(\eta=2.031)$ is lower than $\mathrm{L}_{2}$ $(\eta=2.051)$. As a result, both calculation and experimental results show that the catalytic activity of the $\mathrm{L}_{1}$ ligand is higher than the $\mathrm{L}_{2}$ ligand.

\section{Molecular Electrostatic Potential (MEP)}

The molecular electrostatic potential (MEP) surface of the $L_{1}$ and $L_{2}$ ligands are given in Figure 3. The molecular electrostatic potential (MEP) surfaces shows the reactive sites for electrophilic and nucleophilic reactions of the molecules (Tomasi et al., 2005; Grabowski and Leszczynski, 2006). As seen in Figure 3, the most positive regions (blue in color) are localized on hydrogen atoms. The most negative regions (red in color) are associated with the adjacent $\mathrm{N}$ atoms in the triazole ring and these $\mathrm{N}$ atoms are the most probable active sites to react with metal ions.

\section{CONCLUSIONS}

As a result of experiments, catalytic activity of $\mathrm{L}_{1}$ ligand was found higher than $\mathrm{L}_{2}$ ligand. While the phenyl group has conjugation effect, in ethyl group hyperconjugation is important. The obtained result for $\mathrm{L}_{1}$ ligand can be explained with the hyperconjugation effect of ethyl group. However, the obtained catalytic activity results of $\mathrm{L}_{1}$ and $\mathrm{L}_{2}$ ligand are lower when compared to the catalytic activity of the benzimidazole derivatives.

In addition to this, palladium, platinum and ruthenium complexes of smaller bulky (PBTT) derivatives can be synthesized, and then their applications in many fields, especially in the medical field, can be examined. It is expected palladium, platinum and ruthenium complexes that include (PBTT) derivatives may have more dominant properties than free ligands. The MEP surfaces of the nitrogen atoms in the triazole ring are red in color, ie, negative potential regions.

\section{Acknowledgements}

This study has been supported financially from Munzur University Research Fund (MFTUB015-01). We appreciate Catalysis Research and Application Center, Inonu University (for catalytic activity studies), Faculty of Arts and Sciences Department of Chemistry, Bingol University (for laboratory facilities) and Tunceli Vocational School, Department of Chemistry and Chemical Process Technologies, Munzur University (for laboratory facilities) in Turkey. In addition, the numerical calculations reported in this paper were fully performed at TUBITAK ULAKBIM, High Performance and Grid Computing Center (TRUBA resources).

\section{CONFLICTS OF INTEREST STATEMENT}

The authors declare that there is no conflict of interest in this study.

\section{RESEARCH AND PUBLICATION ETHICS STATEMENT}

The authors declare that they comply with research and publication ethics in this study.

\section{REFERENCES}

Ahirwar, J., Ahirwar, D., Lanjhiyana, S., Jha, A.K., 2017. Synthesis and characterization of 1,2,4triazole- pyridine hybrids as potential antimicrobial, agents. International Journal of Pharmaceutical and Clinical Research, 9(12):702-709.

Bulut, N., Kocyigit, U.M, Gecibesler, I.H., Dastan, T., Karci, H., Taslimi, P., Dastan, S.D., Gulcin I., Cetin, A., 2018. Synthesis of some novel pyridine compounds containing bis-1,2,4-triazole/ thiosemicarbazide moiety and investigation of their antioxidant properties, carbonic anhydrase, and acetyl cholinesterase enzymes inhibition profiles. Journal of Biochemical and Molecular Toxicology, 32(1), Article Number: e22006.

Cansız, A., Çetin, A., Kutulay, P., Koparir, M., 2009. Synthesis of tautomeric forms of 5-(2hydroxyphenyl)-4-substituted-3H-1,2,4-triazole-3thione. Asian Journal of Chemistry, 21(1):617-626.

Çetin, A., Dayan, O., 2009. Transfer hydrogenation of acetophenone catalyzed by in situ generated 2,6bis(5-thioxo-4,5-dihydro-1,2,4-triazole-3-yl)pyridine -ruthenium(II) complexes. Chinese Journal of Chemistry, 27,1-10. 
Coyanis, E.M.; Vedova, D.C.O.; Haas, A.; Winter, M., 2002. Preparation, characterization and thiol-thione tautomeric studies of 2-thiono-4-methyl-5-(2,2,2trifluoro-1-trifluoromethylethyl)-1,3-thiazoline. Journal of Fluorine Chemistry, 117:185-192.

Dege, N., Andac, O., Cansız, A., Çetin, A., Şekerci, M., Dinçer, M., 2004. 5-(Furan-2-yl)-4-(p-tolyl)-2, 4dihydro-1, 2,4-triazole-3-thione. Acta Crystallographica Section E: Structure Reports Online 60(8):o1405-o1407.

Dege, N., Özdemir, N., Çetin, A., Cansız, A., Şekerci, M., Dinçer, M., 2005. 4-Ethyl-5-(2-hydroxyphenyl)2H-1,2,4-triazole-3(4H)-thione. Acta Crystallographica Section E: Structure Reports Online 61(1):o17-o19.

Frisch, M.J., et al., 2010. Gaussian 09, Revision C.01, Gaussian, Inc., Wallingford CT.

Grabowski S.J., Leszczynski, J., 2006. Unrevealing the nature of hydrogen bonds: p-electron delocalization shapes H-bond features, S. J. Grabowski (Ed.): Hydrogen Bonding, New Insights. Kluwer Academic Publishers, New York, p. 491-495.

Gündüzalp, A.B., Parlakgümüş, G., Uzun, D., Özdemir Özmen, Ü., Ozbek, N., Sarı, M., Tunç, T., 2016. Carbonic anhydrase inhibitors: Synthesis, characterization and inhibition activities of furan sulfonylhydrazones against carbonic anhydrase I (hCA I). Journal of Molecular Structure, 1105:332340 .

Ince, S., 2016. Synthesis of new secondary amine benzoylthiourea ligand derivatives: Investigation of catalytic activity in $\mathrm{Pd}$ catalyzed Suzuki cross coupling reactions, $M S c$. Thesis, Science Institute of Mersin University, Mersin, Turkey.

Muneer, C.P., Shalina, B.T., Shafi, P. M., 2014. Synthesis characterization and antioxidant study of a few 3-substituted1,2,4-triazole-5-thiones and their derivatives. International Journal of Chemical Science, 12(1):129-135.

Muthal, N., Ahirwar Jyoti, J., Ahriwar, D., Masih Pankaj, P., Mahmdapure T., Sivakumar, T., 2010. Synthesis, antimicrobial and anti-inflammatory activity of some 5-substituted-3-pyridine-1,2,4triazoles. International Journal of PharmTech Research. 2(4):2450-2455.

Özdemir, İ., Gök, Y., Gurbuz N., Çetinkaya, B., 2007. Benzimidazolylidene carbene ligated palladium catalysis of the Heck reaction in aqueous media. Turkish Journal of Chemistry, 31(4):397-402.

Özdemir Özmen, Ü., Aktan, E., İlbiz, F., Gündüzalp, A.B., Ozbek, N., Sarı, M., Çelik, Ö., Saydam, S., 2014. Characterization, antibacterial, anticarbonic anhydrase II isoenzyme, anticancer, electrochemical and computational studies of sulfonic acid hydrazide derivative and its $\mathrm{Cu}(\mathrm{II})$ complex. Inorganica Chimica Acta, 423:94-203.
Özdemir Özmen , Ü., Özbek, N., Genç, Z.K., İlbiz F., Gündüzalp, A.B., 2017. New bioactive silver(I) complexes: Synthesis, characterization, anticancer, antibacterial and anticarbonic anhydrase II activities. Journal of Molecular Structure, 1138:5-63.

Tomasi, J., Mennucci, B., Cammi, R., 2005. Quantum mechanical continuum solvation models. Chemical Reviews, 105(8):2999- 3094.

Turek, J., Panov, I., Semler, M., Štěpnička, P., Proft, F.D., Z. Padělková Z., Růžička, A., 2014. Palladium(II) complexes of 1,2,4-triazole-based N-heterocyclic carbenes: synthesis, structure, and catalytic activity. Organometallics, 33(12):31083118.

Yiğit, B., Yiğit, M., Özdemir, İ., Çetinkaya, E., 2010. The synthesis of some benzimidazolium salts and use as carbene precursors in the Heck and Suzuki reactions. Heterocycles, 81:943-953. 
Appendix 1. Some optimized geometries for $\mathrm{L}_{1}$ and $\mathrm{L}_{2}$ ligands

\begin{tabular}{|c|c|c|c|c|c|}
\hline \multicolumn{6}{|l|}{$\mathbf{L}_{1}$} \\
\hline \multicolumn{2}{|c|}{ Bond lengths $(\AA)$} & \multicolumn{2}{|l|}{ Angles $\left(^{\circ}\right)$} & \multicolumn{2}{|c|}{ Dihedral angles $\left({ }^{\circ}\right)$} \\
\hline $\mathrm{R}(1,2)$ & 1.406 & $\mathrm{~A}(2,1,6)$ & 122.02 & $\mathrm{D}(6,1,2,3)$ & -0.06 \\
\hline $\mathrm{R}(3,4)$ & 1.406 & $\mathrm{~A}(5,4,17)$ & 118.53 & $\mathrm{D}(6,1,2,8)$ & 178.99 \\
\hline $\mathrm{R}(3,7)$ & 1.086 & $\mathrm{~A}(4,5,6)$ & 124.00 & $\mathrm{D}(11,1,6,5)$ & -179.64 \\
\hline $\mathrm{R}(4,5)$ & 1.406 & $\mathrm{~A}(6,5,9)$ & 116.60 & $\mathrm{D}(2,1,11,12)$ & 0.41 \\
\hline $\mathrm{R}(4,17)$ & 1.466 & $\mathrm{~A}(1,6,5)$ & 118.56 & $\mathrm{D}(2,1,11,14)$ & -179.24 \\
\hline $\mathrm{R}(5,6)$ & 1.334 & $\mathrm{~A}(13,10,14)$ & 111.59 & $\mathrm{D}(2,3,4,5)$ & 0.84 \\
\hline $\mathrm{R}(10,14)$ & 1.368 & $\mathrm{~A}(13,10,15)$ & 125.09 & $\mathrm{D}(2,3,4,17)$ & 178.49 \\
\hline $\mathrm{R}(11,14)$ & 1.386 & $\mathrm{~A}(14,10,15)$ & 123.33 & $\mathrm{D}(7,3,4,5)$ & -177.34 \\
\hline $\mathrm{R}(14,24)$ & 1.474 & $\mathrm{~A}(1,11,12)$ & 122.56 & $\mathrm{D}(17,4,5,9)$ & 157.49 \\
\hline $\mathrm{R}(18,19)$ & 1.315 & $\mathrm{~A}(11,12,13)$ & 108.47 & $\mathrm{D}(5,4,17,21)$ & -143.59 \\
\hline $\mathrm{R}(18,22)$ & 1.766 & $\mathrm{~A}(10,14,24)$ & 125.70 & $\mathrm{D}(1,11,14,24)$ & -158.74 \\
\hline $\mathrm{R}(19,20)$ & 1.374 & $\mathrm{~A}(10,15,16)$ & 92.44 & $\mathrm{D}(12,11,1,6)$ & -179.33 \\
\hline $\mathrm{R}(21,31)$ & 1.468 & $\mathrm{~A}(4,17,20)$ & 123.41 & $\mathrm{D}(12,11,14,24)$ & 178.73 \\
\hline $\mathrm{R}(24,26)$ & 1.095 & $\mathrm{~A}(20,17,21)$ & 109.80 & $\mathrm{D}(18,21,31,32)$ & 81.99 \\
\hline $\mathrm{R}(24,27)$ & 1.089 & $\mathrm{~A}(19,18,21)$ & 111.40 & $\mathrm{D}(27,24,25,28)$ & 62.12 \\
\hline $\mathrm{R}(25,30)$ & 1.094 & $\mathrm{~A}(21,18,22)$ & 123.07 & $\mathrm{D}(27,24,25,29)$ & -178.20 \\
\hline $\mathrm{R}(31,32)$ & 1.531 & $\mathrm{~A}(18,22,23)$ & 92.70 & $\mathrm{D}(32,29,44,45)$ & 177.81 \\
\hline $\mathrm{R}(31,33)$ & 1.096 & $\mathrm{~A}(14,24,25)$ & 112.62 & $\mathrm{D}(14,10,26,27)$ & -179.65 \\
\hline $\mathrm{R}(32,36)$ & 1.095 & $\mathrm{~A}(21,31,34)$ & 107.17 & $\mathrm{D}(3,4,17,20)$ & -142.90 \\
\hline \multicolumn{6}{|l|}{$\mathbf{L}_{2}$} \\
\hline $\mathrm{R}(1,2)$ & 1.406 & $\mathrm{~A}(2,1,6)$ & 122.35 & $\mathrm{D}(6,1,2,3)$ & -0.27 \\
\hline $\mathrm{R}(3,4)$ & 1.406 & $\mathrm{~A}(5,4,28)$ & 118.54 & $\mathrm{D}(6,1,2,8)$ & 179.36 \\
\hline $\mathrm{R}(3,7)$ & 1.085 & $\mathrm{~A}(4,5,6)$ & 123.91 & $\mathrm{D}(11,1,6,5)$ & -179.25 \\
\hline $\mathrm{R}(4,5)$ & 1.407 & $\mathrm{~A}(6,5,9)$ & 116.57 & $\mathrm{D}(2,1,11,12)$ & -50.29 \\
\hline $\mathrm{R}(4,28)$ & 1.466 & $\mathrm{~A}(1,6,5)$ & 118.39 & $\mathrm{D}(2,1,11,14)$ & 175.58 \\
\hline $\mathrm{R}(5,6)$ & 1.333 & $\mathrm{~A}(13,10,14)$ & 111.28 & $\mathrm{D}(2,3,4,5)$ & 0.45 \\
\hline $\mathrm{R}(10,26)$ & 1.764 & $\mathrm{~A}(13,10,26)$ & 125.97 & $\mathrm{D}(2,3,4,28)$ & 178.37 \\
\hline $\mathrm{R}(11,14)$ & 1.390 & $\mathrm{~A}(14,10,26)$ & 122.75 & $\mathrm{D}(7,3,4,5)$ & -178.66 \\
\hline $\mathrm{R}(14,15)$ & 1.440 & $\mathrm{~A}(1,11,12)$ & 123.42 & $\mathrm{D}(28,32,33,35)$ & 69.46 \\
\hline $\mathrm{R}(29,30)$ & 1.314 & $\mathrm{~A}(1,11,14)$ & 127.08 & $\mathrm{D}(5,4,28,31)$ & 28.76 \\
\hline $\mathrm{R}(29,44)$ & 1.764 & $\mathrm{~A}(10,14,15)$ & 124.97 & $\mathrm{D}(1,11,14,15)$ & -21.28 \\
\hline $\mathrm{R}(30,31)$ & 1.375 & $\mathrm{~A}(10,26,27)$ & 92.13 & $\mathrm{D}(12,11,1,6)$ & 174.71 \\
\hline $\mathrm{R}(32,33)$ & 1.435 & $\mathrm{~A}(4,28,31)$ & 123.91 & $\mathrm{D}(11,14,15,17)$ & 86.04 \\
\hline $\mathrm{R}(33,35)$ & 1.398 & $\mathrm{~A}(31,28,32)$ & 109.43 & $\mathrm{D}(21,18,22,31)$ & 171.07 \\
\hline $\mathrm{R}(26,27)$ & 1.350 & $\mathrm{~A}(29,44,45)$ & 92.21 & $\mathrm{D}(14,10,15,16)$ & 176.07 \\
\hline $\mathrm{R}(38,42)$ & 1.086 & $\mathrm{~A}(34,36,41)$ & 119.60 & $\mathrm{D}(4,28,31,30)$ & 179.99 \\
\hline $\mathrm{R}(40,43)$ & 1.087 & $\mathrm{~A}(40,36,41)$ & 120.23 & $\mathrm{D}(32,28,31,30)$ & 0.30 \\
\hline $\mathrm{R}(44,45)$ & 1.349 & $\mathrm{~A}(35,38,40)$ & 120.22 & $\mathrm{D}(4,28,32,29)$ & 179.93 \\
\hline $\mathrm{R}(34,37)$ & 1.086 & $\mathrm{~A}(38,40,43)$ & 119.98 & $\mathrm{D}(3,4,28,31)$ & -149.13 \\
\hline
\end{tabular}

